\title{
A Serological Study of Blood Borne Viral Hepatitis Cases Attending IIMS \& R, Lucknow
}

\author{
Authors \\ Karuna Dubey $^{1 *}$, Shabnam Parveen ${ }^{1}$, Sanjeev Sahai ${ }^{1}$ \\ ${ }^{1}$ Department of Microbiology, Integral Institute of Medical Sciences and Research, Lucknow, India \\ *Corresponding Author \\ Dr Karuna Dubey \\ Department of Microbiology \\ Integral Institute of Medical Sciences and Research, Lucknow, India \\ Email: dubey.karuna08@gmail.com
}

\begin{abstract}
Context: Acute viral hepatitis (AVH) is a major public health problem and is an important cause of morbidity and mortality.

Aim: To study the prevalence of viral Hepatitis $B$ and Hepatitis $C$ cases in patients attending IIMS\&R, Lucknow, U.P.

Material \&Method: Blood samples and clinical information was collected from cases of over a 6 month period ( $1^{\text {st }}$ January 2015 to $30^{\text {th }}$ June 2015). Samples were tested for Hepatitis B surface antigen, antiHCV total antibodies.

Statistical Analysis Used: Fisher's exact test was used and a $P<0.05$ was considered to be statistically significant.

Results: The prevalence rate was found to be $4.5 \%$ in $\mathrm{HBV}$ and $2.5 \%$ for $\mathrm{HCV}$. Out of 1434 patients 66 were Hepatitis B positive and 35 were Hepatitis $C$ virus.57.6\% of the patients of Hepatitis $B$ and $31.4 \%$ of hepatitis $C$ were males. On comparing both $H B V$ and $H C V$ positive viral infections, statistically significant values ( $p \leq 0.05)$ were found in males. About three fourth $(76.9 \%)$ of the patients of hepatitis B and $62.9 \%$ of HCV were found to be literate and belonged to lower and middle socio-economic status having poor hygiene. Statistically significant values were observed in low socio-economic status ( $p \leq .003)$, literacy level $(p \leq 0.01)$, serum bilirubin $(p=0.005)$ and alkaline phosphate $(p=0.002)$ between Hepatitis $B$ and $C$ patients was observed. The results of ELISA test were $100 \%$ while for Rapid card test it was $95 \%$ only Conclusion: Preventive measures should include health education regarding parentral transmission of infection stringent blood banking laws need to be introduced and use of disposable syringes/needles should be made mandatory. Reuse of needles, shaving kits and razor blades should be discouraged. Universal immunization of all infants is desirable to decrease the carrier pool and it is inferred from the present study that Hepatitis B immunization should begin at birth to have greater impact.

Keywords: Viral hepatitis, hepatitis B, hepatitis $C$, Enzyme linked immunoassay
\end{abstract}




\section{INTRODUCTION}

Viral hepatitis is still one of the most common causes of acute and chronic liver disease worldwide. Viral hepatitis is a subject of profound concern and results in about 10,000 new papers each year, from molecular structure to newest treatments. Major new advances have been made in knowledge of these diseases. Acute viral hepatitis is a major public health issue in the developing nations that have inadequate sanitary conditions. Five hepatotropic viruses A to E are now recognized and all are important public health issues, although more so in some countries than others. Three additional viruses, Hepatitis G, TT virus, and SEN-V have been discovered recently, but have to be proved to be hepatotropic and pathogenic to liver ${ }^{1}$.

Hepatitis B virus (HBV) is the most important causative agent of blood borne hepatitis in humans. Hepatitis D Virus (HDV) infection occurs either as a coinfection or superinfection in HBV carriers. Hepatitis- B infection is the major health problem all over the world. The disease is highly variable. The acute Hepatitis-B virus (HBV) infection may be mild, self limiting or it can cause fatal fulminant or sub fulminant hepatic failure in a small percentage of infected persons. The more serious consequences of chronic carrier state are progression to chronic liver disease namely chronic hepatitis, cirrhosis of liver and hepatocellular carcinoma. There are presently about 350 million chronic carriers of HBV in the world population.

Hepatitis C virus (HCV) is the major cause of transfusion non-A, non-B hepatitis and continues to be a major cause of human liver disease throughout the world ${ }^{2}$. Hepatitis C virus (HCV) is a parenterally transmitted virus that is responsible for 170 million cases of chronic hepatitis in the world. About $75-80 \%$ of those persons infected with $\mathrm{HCV}$ tend to become chronic carriers and the majority of these patients are asymptomatic ${ }^{3}$. The noted increase in prevalence over time, as well as the high prevalence among patients may suggest that there is a need to have up to date data of
HBV and HCV infection The information is also important in relation to the adoption of recommendations made by WHO on screening of patients especially pregnant women and offering the at-birth-dose of $\mathrm{HBV}$ vaccine to prevent perinatal transmission for those mothers who test positive.

The study was undertaken to determine the prevalence and risk factors of $\mathrm{HBV}$ and $\mathrm{HCV}$ in patients visiting hospital of Integral Institute Of Medical Science and Research, Lucknow.

\section{MATERIALS AND METHODS STUDY AREA}

The study was conducted in Integral Institute of Medical Sciences and Research from the patients attending the hospital located at Dasauli, Kursi road, Lucknow.

\section{SOURCE OF DATA}

It was a prospective study of 1434 clinically suspected cases of blood borne viral hepatitis referred from the Department of Medicine to the Department of Microbiology for viral markers investigation.

\section{METHODS \\ HEPATITIS DETECTION PROCEDURES}

The cases were screened for the hepatotropic viral markers, Hepatitis B \& C by Rapid ELISA test. Indeterminate cases by rapid test was confirmed by ELISA method. HEPACARD" is a rapid diagnostic method for the detection of hepatitis B virus (J. Mitra \& Co. Ltd) is a one step immunoassay based on antigen capture 'sandwich' principle. The method uses monoclonal antibodies conjugated to colloidal gold and polyclonal antibodies immobilized on a nitrocellulose strip in a thin line. ERBA LISA HEPATITIS B is a solid phase immunoassay for the qualitative detection of HBsAg in human serum and plasma. The 4th Generation HCV TRI-DOT is a rapid diagnostic method for the detection of hepatitis $\mathrm{C}$ virus and has been developed and designed with increased sensitivity for core and NS3 antibodies using a 
unique combination of modified $\mathrm{HCV}$ antigens. The 3rd generation HCV MICROLISA is an in vitro qualitative enzyme linked immunosorbent assay for the detection of antibodies against $\mathrm{HCV}$ (anti-HCVs) in human serum or plasma.

\section{RESULTS}

The study was done in Integral Institute of Medical Science and research to study the serological prevalence of Hepatitis B and Hepatitis C. The study was conducted in 1434 patients and was studied according to their age and sex relations, literacy, socioeconomic factors, risk factors and on the basis of symptoms present. Out of 1434 patients 66 were Hepatitis B positive and 35 Hepatitis $\mathrm{C}$ virus. In the present study, about three fourth $(76.9 \%)$ of the patients of hepatitis B were found to be literate and belong to lower socio-economic status having poor hygiene whereas in our study the prevalence of $\mathrm{HCV}$ in illiterates was found to be $62.9 \%$ and belonged to middle socio-economic status, $45.7 \%$ of hepatitis $\mathrm{C}$ belonged to middle socio-economic status. The risk factors were present in all the patients of Hepatitis B \& Hepatitis C. Anorexia, nausea, fatigue and vomiting were present in majority of the patients of Hepatitis B and C.

Table-1: Distribution of Hepatitis B and C patients

\begin{tabular}{|l|c|c|c|}
\hline & $\begin{array}{c}\text { Hepatitis B } \\
\text { positive }\end{array}$ & $\begin{array}{c}\text { Hepatitis C } \\
\text { positive }\end{array}$ & Total \\
\hline & $\mathrm{N}(\%)$ & $\mathrm{N}(\%)$ & $\mathrm{N}(\%)$ \\
\hline In patients & $40(60.6)$ & $27(77.1)$ & $67(67.0)$ \\
\hline $\begin{array}{l}\text { Out } \\
\text { patients }\end{array}$ & $26(39.4)$ & $8(22.9)$ & $34(33.0)$ \\
\hline Total & $66(100.0)$ & $35(100.0)$ & $101(100.0)$ \\
\hline
\end{tabular}

Table-2: Age and sex distribution of Hepatitis B and C patients

\begin{tabular}{|c|c|c|c|c|c|c|c|}
\hline \multirow{3}{*}{$\begin{array}{l}\text { Age } \\
\text { groups } \\
\text { (years) }\end{array}$} & \multirow[t]{3}{*}{ Total } & \multicolumn{2}{|l|}{ Male } & \multirow[t]{3}{*}{$\mathrm{P}$ value } & \multicolumn{2}{|l|}{ Female } & \multirow[t]{3}{*}{$\mathrm{P}$ value } \\
\hline & & $\begin{array}{l}\text { Hepatitis } \\
\text { positive }\end{array}$ & $\begin{array}{l}\text { Hepatitis C } \\
\text { Positive }\end{array}$ & & Hepatitis B positive & $\begin{array}{l}\text { Hepatitis C } \\
\text { positive }\end{array}$ & \\
\hline & & $\mathrm{N} \%$ & $\mathrm{~N} \%$ & & $\mathrm{~N} \%$ & N\% & \\
\hline$<10$ & 11 & $3(7.9)$ & $2(18.2)$ & N.A & $3(10.7)$ & $3(12.5)$ & N.A \\
\hline $10-20$ & 22 & $12(31.6)$ & $3(27.3)$ & N.A & $4(14.3)$ & $3(12.5)$ & N.A \\
\hline $20-30$ & 25 & $11(28.9)$ & $1(9.1)$ & N.A & $7(25.0)$ & $6(25.0)$ & 0.78 \\
\hline $30-40$ & 18 & $4(10.5)$ & $3(27.3)$ & N.A & $5(17.9)$ & $6(25.0)$ & 0.76 \\
\hline $40-50$ & 15 & $3(7.9)$ & $1(9.1)$ & N.A & $7(25.0)$ & $4(16.7)$ & N.A \\
\hline$>50$ & 10 & $5(13.2)$ & $1(9.1)$ & N.A & $2(7.1)$ & $2(8.3)$ & N.A \\
\hline Total & 101 & $38(100.0)$ & $11(100.0)$ & $\begin{array}{l}0.00 \\
\text { (sign.) }\end{array}$ & $28(100.0)$ & $24(100.0)$ & 0.57 \\
\hline
\end{tabular}

\begin{tabular}{|l|l|l|}
\hline & HEPATITIS B POSITIVE & HEPATITIS C POSITIVE \\
\hline Mean \pm SD & $39.29 \pm 16.41$ & $45.91 \pm 16.06$ \\
\hline
\end{tabular}

Table-3: Sex distribution of Hepatitis B and C patients

\begin{tabular}{|l|c|c|c|c|}
\hline \multirow{2}{*}{ Sex } & & $\begin{array}{c}\text { Hepatitis B } \\
(\mathrm{n}=66)\end{array}$ & $\begin{array}{c}\text { Hepatitis C } \\
(\mathrm{n}=35)\end{array}$ & \multirow{2}{*}{ P value } \\
\cline { 2 - 4 } & Total & $\mathrm{N}(\%)$ & $\mathrm{N}(\%)$ & \\
\hline Male & 49 & $38(57.6)$ & $11(31.4)$ & $0.00^{*}$ \\
\hline Female & 52 & $28(42.4)$ & $24(68.6)$ & 0.57 \\
\hline
\end{tabular}


Table-4: Distribution of Hepatitis B and C patients according to education

\begin{tabular}{|l|l|l|l|l|}
\hline Education level & Total & $\begin{array}{l}\text { Hepatitis B } \\
\mathrm{N}(\%)\end{array}$ & $\begin{array}{l}\text { Hepatitis C } \\
\mathrm{N}(\%)\end{array}$ & $\begin{array}{l}\mathrm{P} \\
\text { value }\end{array}$ \\
\hline Illiterate & 29 & $16(24.2)$ & $13(37.1)$ & 0.57 \\
\hline Primary & 24 & $18(27.3)$ & $6(17.1)$ & $0.01^{*}$ \\
\hline High school to Intermediate & 24 & $17(25.8)$ & $7(20.0)$ & $0.04^{*}$ \\
\hline Graduate + & 24 & $15(22.7)$ & $9(25.7)$ & 0.22 \\
\hline
\end{tabular}

Table-5: Distribution of Hepatitis B and C patients according to Socio Economic Status (SEO)

\begin{tabular}{|l|l|l|l|l|}
\hline SES & Total & Hepatitis B N(\%) & Hepatitis C N(\%) & P value \\
\hline High & 32 & $20(30.4)$ & $12(34.3)$ & 0.15 \\
\hline Medium & 39 & $23(34.8)$ & $16(45.7)$ & 0.26 \\
\hline Low & 30 & $23(34.8)$ & $7(20.0)$ & 0.003 \\
\hline
\end{tabular}

Table-6: Distribution of Hepatitis B and C patients according to risk factors

\begin{tabular}{|l|l|l|l|l|}
\hline Presence of risk factors & Total & Hepatitis B N(\%) & Hepatitis C N(\%) & p- value \\
\hline Unsterilized Needle use & 29 & $20(30.3)$ & $9(25.7)$ & $0.04^{*}$ \\
\hline $\begin{array}{l}\text { Drinking/smoking/ } \\
\text { Drug abuse }\end{array}$ & 23 & $15(22.7)$ & $8(22.9)$ & 0.99 \\
\hline Dental procedures & 9 & $5(7.6)$ & $4(11.4)$ & 0.66 \\
\hline Blood donation & 2 & $1(1.5)$ & $1(2.9)$ & 0.45 \\
\hline $\begin{array}{l}\text { Contact with hepatitis } \\
\text { case }\end{array}$ & 1 & $1(1.5)$ & $0(0.0)$ & 0.97 \\
\hline $\begin{array}{l}\text { Contact with multiple } \\
\text { sex workers }\end{array}$ & 2 & $2(3.0)$ & $0(0.0)$ & 0.93 \\
\hline Minor surgery & 6 & $5(7.6)$ & $1(2.9)$ & 0.47 \\
\hline Major surgery & 3 & $2(3.0)$ & $1(2.9)$ & 0.67 \\
\hline Infected spouse & 3 & $2(3.0)$ & $1(2.9)$ & 0.76 \\
\hline Blood Transfusion & 3 & $1(1.5)$ & $2(5.7)$ & $0.01^{*}$ \\
\hline Unknown & 50 & $32(48.5)$ & $18(51.4)$ & $0.04^{*}$ \\
\hline
\end{tabular}

Table-7: Distribution of Hepatitis B and C patients according to symptoms

\begin{tabular}{|l|c|c|c|c|}
\hline Presence of symptoms & & $\begin{array}{c}\text { Hepatitis B } \\
(\mathrm{n}=66)\end{array}$ & $\begin{array}{c}\text { Hepatitis C } \\
(\mathrm{n}=35)\end{array}$ & $\begin{array}{c}\mathrm{p}- \\
\text { value }\end{array}$ \\
\cline { 2 - 5 } & Total & $\mathrm{N}(\%)$ & $\mathrm{N}(\%)$ & \\
\hline Anorexia & 90 & $59(89.4)$ & $31(88.6)$ & 0.72 \\
\hline Nausea & 86 & $57(86.4)$ & $29(82.9)$ & 0.57 \\
\hline Fatigue & 93 & $62(93.9)$ & $31(88.6)$ & 0.20 \\
\hline Vomiting & 82 & $53(80.3)$ & $29(82.9)$ & 0.87 \\
\hline Fever & 80 & $50(75.8)$ & $30(85.7)$ & 0.29 \\
\hline Headache & 81 & $52(78.8)$ & $29(82.9)$ & 0.72 \\
\hline Arthralgia & 75 & $47(71.2)$ & $28(80.0)$ & 0.39 \\
\hline Myalgia & 58 & $32(48.5)$ & $26(74.3)$ & $0.01^{*}$ \\
\hline Chronic diarrhea & 34 & $14(21.2)$ & $20(57.1)$ & $0.001^{*}$ \\
\hline Loss of weight & 56 & $32(48.5)$ & $24(68.6)$ & 0.06 \\
\hline Pruritis & 62 & $40(60.6)$ & $22(62.9)$ & 0.89 \\
\hline Pain in right hypchondrium & 39 & $21(31.8)$ & $18(51.4)$ & 0.06 \\
\hline Swelling in abdomen & 63 & $34(51.5)$ & $29(82.9)$ & $0.003^{*}$ \\
\hline
\end{tabular}

Table-8: Comparison of Liver Function Tests

\begin{tabular}{|l|c|c|c|}
\hline LFT PARAMETERS & $\begin{array}{c}\text { Hepatitis B } \\
(\mathrm{n}=66)\end{array}$ & $\begin{array}{c}\text { Hepatitis C } \\
(\mathrm{n}=35)\end{array}$ & p-value $^{1}$ \\
\hline Mean Serum bilirubin & $1.36 \pm 0.72$ & $1.81 \pm 0.77$ & $0.005^{*}$ \\
\hline Mean ALT & $189.93 \pm 69.51$ & $164.00 \pm 55.44$ & 0.06 \\
\hline Mean AST & $182.34 \pm 72.13$ & $158.77 \pm 61.61$ & 0.10 \\
\hline Mean Alkaline phosphate & $216.35 \pm 70.12$ & $176.08 \pm 39.75$ & $0.002^{*}$ \\
\hline
\end{tabular}




\section{DISSCUSION}

Hepatitis B virus (HBV) and hepatitis $\mathrm{C}$ virus (HCV) are the most common causes of chronic liver disease (CLD) worldwide, and can lead to cirrhosis and hepatocellular carcinoma $\mathrm{HCC}^{4}$ Several studies on AVH are available from India and abroad that have reported varying prevalence of hepatotropic viruses- HBV (7.3-42\%), and HCV $(1.16-10.6 \%)^{5}$. In a study, done by Jain et al., ${ }^{6} 2013$ in Lucknow ,the prevalence was identified to be the HBV $(16.10 \%$ cases $)$ and HCV (11.98\%). In the present study the prevalence rate was found to be $4.5 \%$ in $\mathrm{HBV}$ and $2.5 \%$ for $\mathrm{HCV}$. A low prevalence of $\mathrm{HCV}$ infection (4\%) was seen in Aligarh and its surrounding region. Prevalence levels similar to ours $(2.5 \%)$ have been reported from South India by Sumarthy et.al., ${ }^{7} 1993$. On the contrary, a very high prevalence $(37.5 \%)$ of $\mathrm{HCV}$ has been reported from Delhi by Singh et al., ${ }^{8} 1991$. The male female ratio for HBV was 1.5:1 whereas in $\mathrm{HCV}$ infection male female ratio of 1:2 was found and on comparing both $\mathrm{HBV}$ and $\mathrm{HCV}$ positive viral infections statistically significant values were found in males $\mathrm{p} \leq 0.00$. In the present study, about three fourth $(76.9 \%)$ of the patients of hepatitis B were found to be literate and belong to lower socio-economic status having poor hygiene. On contrary an increased prevalence in illiterates was reported by Uppal et al., 2009, ${ }^{9}$ from Delhi. In our study the prevalence of $\mathrm{HCV}$ in literates was found to be $62.9 \%$ and belonged to middle socio-economic status, similar to findings by Wang et al., ${ }^{10} 2002$ from Taiwan. Statistically significant values were observed in low socio-economic status $\mathrm{p} \leq .003)$ and literacy $(\mathrm{p} \leq$ .01 ) while comparing $\mathrm{HBV}$ and $\mathrm{HCV}$ positive patients. The risk factors associated with $\mathrm{HBV}$ infection were unsterilized needle use $(30.3 \%)$ dental manipulations $(7.6 \%)$, surgical operations (3.0\%), previous blood transfusion (1.5\%), HBV infection in the family $(1.5 \%)$ whereas in $\mathrm{HCV}$ positive patients unsterilized needle use $(25.7 \%)$, smoking \& drinking (22.9\%), major surgery
(2.9\%), and blood transfusion $(5.7 \%)$ were the main possible risk factors.

None of the patients gave the familial history nor a history of sex with multiple partners. On comparing the risk factors statistically significant values were observed in unsterilized needle use $(\mathrm{p} \leq .04)$ and for blood transfusion $(\mathrm{p} \leq .01)$ factors. Similarly no history for possible route of transmission could be elucidated in $52 \%$ cases in HBV \&HCV cases. Majority (52\%) of the cases with HBV \& HCV were unknown about their mode of acquiring infection and significant values $(\mathrm{p} \leq .04)$ were observed on comparing both viral infections. Similar observations were seen in a study done in Delhi by Thakur et al., ${ }^{11}$ 1999. In our study the main clinical manifestations for HBV positive patients were fatigue $(93.9 \%) \&$ anorexia $(88.6 \%)$ and in one third of the patients with vomiting (80.3\%) ,fever(75.8\%) and headache $(78.8 \%)$. However in $\mathrm{HCV}$ positive patients fatigability $(88.6 \%)$, anorexia $(88.6 \%)$, fever $(85.7 \%)$, nausea $(82.9 \%)$, vomiting $(82.9 \%)$ were the main clinical manifestations. Statistically significant difference was found in clinical manifestations of myalgia ( $p$ - value <.01) abdominal pain ( $p$ - value <.003) and chronic diarrhoea ( $\mathrm{p}$ - value< .001) .Similar findings were observed by Morsy et al., 122015 Egypt. The result of AST value in Hepatitis B was found to be in the range of $182.32 \pm 72.03$ and ALT value was observed as $189.93 \pm 69.55$. The AST value in Hepatitis C was found to be $158.77 \pm 61.61$ and ALT value was observed as 164.00 \pm 55.44 . Sumarthy et al., ${ }^{7} 1993$ Madurai studied that Mean AST and ALT levels in Hepatitis B cases were almost twice those in Hepatitis C cases. There was significant difference in serum bilirubin $(\mathrm{p}=0.005)$ and alkaline phosphate $(\mathrm{p}=0.002)$ between Hepatitis B and C patients._A large majority $(42.57 \%)$ of the patients with Hepatitis B \& Hepatitis C were young (2040years) and had normal ALT (47.5\%), similar findings were observed in a study done by Khokhar et. al., ${ }^{13} 2004$ from Pakistan 
In our study it was observed that the results of ELISA test was $100 \%$ while for Rapid card test it was $95 \%$, Torane et al., ${ }^{14} 2007$ from Mumbai also reported that the rapid tests were inferior compared to ELISA. No case of $\mathrm{HBV}$ and $\mathrm{HCV}$ co-infection was found in our study however HBV and HCV co-infection was reported by Jain et al., ${ }^{6} 2013$ in Lucknow.

Table 9: Prevalence of hepatitis viruses compared with that of other studies

\begin{tabular}{|c|c|c|c|c|c|c|}
\hline Authors & $\begin{array}{l}\text { Year of } \\
\text { study }\end{array}$ & Place of study & Total samples & $\begin{array}{l}\mathrm{HBV}(\% \\
\text { positive })\end{array}$ & $\begin{array}{l}\mathrm{HCV}(\% \\
\text { positive }\end{array}$ & Comments \\
\hline Tandon et al & 1984 & New Delhi & $\begin{array}{l}100 \\
78\end{array}$ & $\begin{array}{c}42 \\
9\end{array}$ & & $\begin{array}{c}\text { Adults } \\
\text { Children }\end{array}$ \\
\hline Kaur et al & 2002 & New Delhi & $\begin{array}{l}177 \\
129\end{array}$ & $\begin{array}{l}19.8 \\
8.6\end{array}$ & $\begin{array}{l}3.4 \\
3.1\end{array}$ & $\begin{array}{c}\text { Adults } \\
\text { Children }\end{array}$ \\
\hline Poddar et al & 2002 & Chandigarh & 172 & 7.6 & 1.16 & $\begin{array}{c}\text { Children } \\
(<14 \text { years })\end{array}$ \\
\hline Hussain et al & 2006 & New Delhi & 1932 & 16.61 & 2.02 & Adults \\
\hline Kumar et al & 2007 & Chandigarh & 685 & 7.3 & 2.8 & $\begin{array}{c}\text { Individuals aged } 10- \\
70 \text { years }\end{array}$ \\
\hline Irshad et al & 2010 & New Delhi & 74 & 12.3 & 10.6 & Adults \\
\hline Jain et al & 2012 & Lucknow & $\begin{array}{l}124 \\
143\end{array}$ & $\begin{array}{l}23.38 \\
9.79\end{array}$ & $\begin{array}{l}12.90 \\
11.18\end{array}$ & $\begin{array}{c}\text { Adults } \\
\text { Children }\end{array}$ \\
\hline & Present study & Lucknow & 1434 & 4.5 & 2.5 & $\begin{array}{c}\text { Individuals aged 5- } \\
70 \text { years }\end{array}$ \\
\hline
\end{tabular}

\section{CONCLUSION}

Hepatitis B and C viruses infection are one of the commonest cause of blood borne hepatitis worldwide. Hepatitis is an emerging infection in India whose long term implications will be felt in the decades to come. The prevalence rate of HBV infection and HCV infection in India is within the range of $3 \% \& 1-1.5 \%$ respectively. In our study the prevalence rate of $\mathrm{HBV}$ infection and $\mathrm{HCV}$ infection was found to be $4.6 \%$ and for $\mathrm{HCV}$ $2.5 \%$. Majority of infected patients (52\%) remained asymptomatic during the course of disease and long term complications of the disease are hepatic disorders and hepatocellular carcinoma. Thus initial screening becomes very important for the early recognition of the disease and to prevent its spread \& complications. The preventive measures include health education regarding parentral transmission of infection stringent blood banking laws need to be introduced and use of disposable syringes/needles should be made mandatory. Reuse of needles, shaving kits and razor blades should be discouraged. All this is not possible without increased public awareness of the magnitude and implications of this chronic infection and its mode of spread. Health authorities have to include hepatitis B and C on their radar as a disease, which can result in significant morbidity and mortality in the years to come. To confirm the findings of our study a larger population study is needed.

\section{ACKNOWLEDGEMENT}

The authors acknowledge to Dr. Sanjeev Sahai, Professor \& Head of the Department of Microbiology; Integral Institute of Medical Sciences, Lucknow, for his utmost guidance and help throughout the study. The untiring inspiration, keen interest, unfailing patience, valuable suggestions, pain taking supervision has inspired me. In the process, I have imbibed values to carry on working with zeal and knowledge. 


\section{REFERENCES}

1. Singh V, Yachha SK, Thapa BR, Mehta S. Antibiotics to hepatitis C virus (anti-HCV) in children. Indian J Pediatr 199;28:153231.

2. Gupta MC, Mahajan BK. Viral hepatitis (ICD-BI5-B-19) In Text book of preventive and social medicine $3^{\text {rd }}$ ed. New Delhi: Jaypee Brothers, 2003; 210-15.

3. M Moorthy, HD Daniel, G Kurian, *P Abraham An Evaluation Of Saliva As An Alternative To Plasma For The Detection Of Hepatitis C Virus Antibodies Indian J Med Microbiol.2008: 26(4):327-32.

4. Shanmugam Saravana, Vijayakumar Velu1, Subhadra Nandakumar, Vidya Madhavan, Uma Shanmugasundaram, Kailapuri G. Murugavel, Pachamuthu Balakrishnan, Nagalingeswaran Kumarasamy, Suniti Solomon, Sadras Panchatcharam Thyagarajan Hepatitis B virus and hepatitis $C$ virus dual infection among patients with chronic liver disease. J Microbiol Immunol Infect. 09;42:122-12.

5. Kaur R, Gur R, Berry N, Kar P. Etiology of endemic viral hepatitis in urban North India. Southeast Asian J Trop Med Public Health 2002;33:845-8.

6. P Jain, S Prakash, S Gupta, KP Singh, S Shrivastava, DD Singh, J Singh, *A Jain Prevalence of hepatitis A virus, hepatitis B virus, hepatitis $C$ virus, hepatitis $D$ virus and hepatitis $\mathrm{E}$ virus as causes of acute viral hepatitis in North India: A hospital based study Indian Journal of Medical Microbiology, (2013) 31(3): 261265.

7. Sumarthy S, Valliammai T, Thyagarajan SP, Malathy S, Madanagopalan N, Sankaranarayanan V, et al. Prevalence of hepatitis $\mathrm{C}$ virus infection in liver disease, renal disease and voluntary blood donors in South India. Ind J Med Microbiol 1993; 11: 291.

8. Singh S, Mohanty A, Joshi YK, Deka D, Mohanty S, Panda KS. Mother to child transmission of Hepatitis E virus. Indian J Pediatr 2003;30:37-9.

9. Uppal Y1, Garg S, Malhotra S, Singh MM, Gupta VK, Mishra B, Singh SVHepatitis B and C virus infection in an urban slum of Northern India. J Commun Dis. 2009 ;41(3):201-4.

10. Chong-shan wang, ting-tsung chang, weijen yao, and pesus chou a-comparison of hepatitis $b$ virus and hepatitis $c$ virus prevalence and risk factors in a community-based study am. j. trop. med. hyg., 66(4), 2002, 389-393.

11. Thakur SK, Gupta RM, Rao MKK, Dham SK. Hepatitis B carrier - a study of possible routes of acquiring the infection. Ind J Gastroenterol 1999;18: S23.

12. Khairy H. Morsy Mohamed A.A. GhalionyTarek T.H. El Melegy Mohamed A.A. Ghaliony Clinical, laboratory, and virological characteristics of patients with positive hepatitis B surface antigen in Upper Egypt Department of Tropical Medicine and Gastroenterology, Sohag University Hospital,Faculty of Medicine, Sohag University,Sohag, The Egyptian Society of Internal Medicine 15, 27:32-37.

13. Khokhar N1, Gill ML, Malik GJ.General seroprevalence of hepatitis $\mathrm{C}$ and hepatitis $\mathrm{B}$ virus infections in population, $\mathrm{J}$ Coll Physicians Surg Pak, 2004;14(9):534-6.

14. Torane V P, Shastri J S. Comparison of ELISA and rapid screening tests for the diagnosis of HIV, hepatitis B and hepatitis $\mathrm{C}$ among healthy blood donors in a tertiary care hospital in Mumbai. Indian J Med Microbiol, 2008; 26:284. 